\title{
EDITORIAL
}

En la presente edición el lector encontrará una diversidad de temáticas relativas a la seguridad en el sistema internacional, tanto a nivel endógeno como exógeno, denotando la transversalidad del sector en las relaciones internacionales. Los artículos que componen esta edición han sido agrupados en dos secciones temáticas: Seguridad, geopolítica y amenazas internacionales y Asuntos transversales del sistema internacional contemporáneo.

\section{Seguridad, geopolítica y amenazas internacionales}

En la primera sección temática presentamos los siguientes artículos:

Cambios y oportunidades de la globalización económica. Es un artículo que analiza empíricamente los elementos principales del actual proceso de globalización económica: apertura comercial, flujo de la inversión extranjera directa y movilidad de capitales, para proponer herramientas críticas frente a los aspectos positivos y negativos a los que se someten las sociedades nacionales, en el abordaje de los gobiernos locales frente a ellos, considerando trascendente a su vez la integración desde las instituciones internacionales, para acortar la brecha económica entre países ricos y pobres.

La geopolítica de la reforma China. Analiza los retos de tal política exterior en el orden geopolítico regional de Asia, mediante el estudio de acontecimientos recientes, en especial las disputas territoriales en el Mar del Sur de China y examina la presión regional como promotora de nuevos rumbos en sus proyecciones geopolíticas, por ejemplo: la ejecución del proyecto Nueva Ruta de la Seda y la profundización de la cooperación con Rusia. Adicional al factor exógeno que representa Estados Unidos de América en Asia Pacífico, a través de la denominada Larga Paz, generando rotundos cambios debido al constante aumento de la economía china y el aumento de los gastos militares, desafiando a otros poderes regionales asiáticos como India y Japón para contrarrestar la influencia China en la región, que observa la participación efectiva de otros 
socios como Malasia y Filipinas, proponiendo una actitud multidireccional hacia el Este y el Oeste de sus fronteras.

Prácticas de seguridad en América Latina durante la Posguerra Fría (1992-2010): ¿Complejos regionales o Comunidades pluralistas de seguridad? Muestra cómo el nuevo regionalismo de seguridad en América, durante la Posguerra Fría, no aporta suficiente evidencia empírica comparada que permita identificar la existencia de Complejos Regionales de Seguridad (CRS) o Comunidades Pluralistas de Seguridad (CPS). Se estudian desde dos indicadores las prácticas de seguridad. Ellos son: disputas interestatales militarizadas mediante estadísticas descriptivas y modelos econométricos, y la persistencia de la hipótesis de conflicto en instrumentos programáticos de defensa mediante el análisis de contenido. Se concluye que el abordaje más apropiado lo ofrecen los CRS dada la persistencia de la amenaza y del uso de la fuerza como práctica de seguridad. La primacía de la agenda estadounidense en América del Norte, América Central y el Caribe implican la presencia de un CRS centrado por su proyección de poder e influencia mundial, mientras que en América del Sur se presenta un CRS estándar. En el nivel subregional, América Central y la Zona Andina constituyen subcomplejos, mientras que el Cono Sur, una comunidad pluralista de seguridad.

Narcotráfico y el desafío a la seguridad en la triple frontera andina. Muestra cualitativamente cómo el narcotráfico es la principal manifestación del crimen organizado en dicho territorio de fronteras permeadas, donde las vías fluviales y terrestres sin control resultan ser rutas principales para llevar droga desde Bolivia y Perú hacia Chile, revalorizando la zona como estratégica, que históricamente bajo el paradigma clásico de seguridad ha sido protagonista de disputas territoriales persistentes y de origen decimonónico. Aborda la problemática desde el territorio, desde los contenidos de la nueva agenda de seguridad internacional, y como amenaza a la seguridad, en sus particularidades nacionales y subnacionales.

Chile y la guerra de Corea. Un episodio de la política exterior chilena. Explica a través del análisis documental de archivos, fuentes diplomáticas y secundarias, y dentro del contexto de la Guerra Fría, la posición asumida por Chile como consecuencia de las influencias ocurridas en Latinoamérica. El enfrentamiento Este-Oeste se presentó como una tentación política para Chile en cuanto a las alianzas militares se refiere, desligándolo posiblemente de Washington. Los resultados se develaron en una estrategia plagada de variables con predominio económico y diplomático, sometidas a lógicas estratégicas de alianzas en Seguridad Hemisférica. 


\section{Asuntos transversales del sistema internacional contemporáneo}

En la segunda sección temática de la primera edición del año 2017, presentamos:

Relaciones internacionales, política tecnológica, desarrollo y proliferación: análisis del caso argentino. Recorre medio siglo de tecnología espacial gaucha, de estirpe capital intensiva, considerada sensible por los países centrales, y que dominan la contextualización de territorios semiperiféricos y periféricos. Esta tecnología implica niveles importantes de industrialización, pero también de poder militar, explicando cómo funciona la disciplina de las Relaciones Internacionales a partir de una política tecnológica, permitiéndose mostrar los principales resultados de este sector transversal y supranacional.

La justicia transicional: la llave hacia una salida negociada al conflicto armado colombiano. Resalta la pertinencia de los mecanismos pacíficos de resolución de conflictos, delimitando el concepto de justicia transicional, desde la necesidad de reconstruir sociedades afectadas por la violencia, con el fin de facilitar la transición de escenarios bélicos a contextos de paz, de restablecimiento democrático y de respeto por los derechos humanos. Colombia ha desarrollado novedosos mecanismos de Justicia transicional que han logrado consolidarse como instrumentos necesarios para la construcción de paz en el país, y sin los cuales no se podría pensar en una salida concertada al conflicto armado interno, que debe dirimir los dilemas críticos entre perdón y castigo.

Intervencionismo y medio ambiente: el caso de la Amazonía brasileña. Debate cualitativamente los conceptos relativos a la internacionalización de la Amazonía y la soberanía de los Estados en el sector ambiental, reflexionando desde la concepción del Sur, especialmente brasilera, y del Norte, que confronta los enfoques de los países desarrollados y las naciones en vías de desarrollo, en las relaciones internacionales. Identifica como principal obstáculo, las nociones divergentes de soberanía y responsabilidad ambiental de los Estados.

Excursionismo internacional y secuestros en la frontera de México, 1997-2016. Comprende la tendencia positiva y en crecimiento del turismo al territorio azteca, ubicándolo en el top 10 mundial de destinos preferidos por los viajeros. Sin embargo, la recepción de excursionistas internacionales en la frontera se ha visto fuertemente reducida; tal tendencia negativa, si bien tuvo su inicio con los atentados terroristas del 11S, se profundizó a partir del incremento de secuestros registrados en Estados fronterizos. Se analiza la tendencia negativa desde un Modelo Estructural de Vectores Autorregresivos, que adiciona a la operación, el PIB de EE. UU. Los resultados obtenidos son congruentes con la teoría del 
turismo, que muestra que el crecimiento de los secuestros provoca contracciones en la llegada de excursionistas, mientras que el crecimiento de la economía estadounidense tiene el efecto contrario.

Finalizando, Política exterior colombiana 2010-2014: ¿giro a la autonomía?, identifica actuaciones no tradicionales de la política exterior cafetera, tales como diversificación de socios comerciales, participación activa en instancias multilaterales y protagonismo en temas álgidos de la región, las cuales pretenden lograr márgenes de autonomía sin confrontar a EE. UU. Una especie de softlaw donde un marco conceptual refiere a la autonomía en Relaciones Internacionales, una reconstrucción de la evolución de la política exterior colombiana bajo el concepto de Réspice Polum.

Esperamos saciar las ansias de nuestros reconocidos y fieles lectores, recorriendo el escenario tradicional de la escuela y guerras clásicas hasta la horizontalización del sistema internacional, donde proliferan asuntos transversales y se muta a enfrentamientos asimétricos y de predominio intraestatal, pero con fuertes incidencias exógenas, que los mantienen, adaptan y desarrollan, dentro de un escenario mundial de facha legal pero con elementos funcionales ilegales.

\section{Diana Patricia Arias Henao}

Editora

Doctora en Relaciones Internacionales revistafaries@unimilitar.edu.co 


\section{EDITORIAL NOTE}

In this issue, the lector will find a diversity of topics related with security in the international system, concerning internal as well as foreign matters. These articles evidence the transversal nature of the international relations field. The texts making up this issue have been grouped into two topic sections: Security, Geopolitics, and International Threats and Transversal Issues of the Contemporaneous International System.

\section{Security, Geopolitics, and International Threats}

In the first topic section, we present the following articles:

Changes and opportunities of Economic Globalization, an article empirically analyzing the main elements of the current economic globalization process: commercial liberalization, the flow of direct foreign investment, and capital mobilization, in order to propose critical tools for both positive and negative features to which national societies are subjected, the proceedings implemented by local governments, and, in turn, the transcendence of the integration to international institutions to narrow the gap between rich and poor countries.

The Geopolitics of the Chinese Reform considers the challenges of such foreign politics in the regional geopolitical order of Asia by means of the study of recent happenings, particularly, the territorial disputes in China's South Sea; also, it is examined the regional pressure which promotes new paths in China's geopolitical projections, as the New Silk Route and the deepening of the cooperation with Russia. In addition, the exogenous factor represented by the USA in the Pacific Asia is considered, through the so-called Lasting Peace, generating dramatic changes due to the constant increase in the Chinese economy and in military expenses. The consequence is a challenge to other Asian regional powers as India and Japan to counteract the Chinese influence in the region, while China enjoys the effective participation of other partners as Malaysia and the Philippines proposing a multidirectional attitude towards the East and West of its national borders. 
Security Practices in America during the post-Cold War (1992-2010): Regional Complexes or Pluralistic Security Communities? shows the way the new security regionalism in America during the post-Cold War period does not offer enough compared empirical evidence in order to identify the existence of Regional Security Complexes (RSC) or Pluralistic Security Communities (PSC). These security practices are analyzed using two indicators: militarized inter-state disputes - by means of descriptive statistics and econometric models - and the persistence of the conflict hypothesis in programmatic instruments of defense through content analysis. The conclusion is that the most appropriate approach is allowed by the RSC, due to the persistence of the threat and the use of force as security practice. The primacy of the American agenda in North America, Central America, and the Caribbean implies the presence of a RSC centered on its power projection and worldwide influence, while in South America there is a standard RSC. At the sub-regional level, Central America and the Andean zone constitute sub-complexes, whereas in the Southern extreme of the continent the occurrence is that of a pluralistic community.

Drug Trafficking and the Challenge to Security in the Triple Andean Borderline qualitatively showcases the way drug trafficking is the main manifestation of organized crime in that area of vulnerable border lines, where river and terrestrial routes are not controlled, resulting in main highways for the transportation of drugs from Bolivia and Peru to Chile and transforming it into a strategic zone, one that historically has been subjected to the classical paradigm of security and has witnessed persistent territorial disputes since the 1800s. The issue is presented from a territorial perspective, from the contents of the new agenda for international security and as a threat to security both nationally and subnationally.

Chile and the Korean War. An Episode of the Chilean Foreign Politics explains by means of documentary analysis of files, diplomatic sources and other secondary ones, and within the context of the Cold War, the position assumed by Chile as a consequence of the influence of actors over Latin America. The war between Eastern and Western nations was similar to a political temptation for Chile when it comes to military alliances, possible de-attaching it from Washington. The results evidenced a strategy full of variables, as the economic and diplomatic predominance, subjected to strategic logics for Hemispheric Security alliances. 


\section{Transversal Issues of the Contemporaneous International System}

In the second topic section of the first issue for 2017 we present:

International Relations, Technological Politics, Development, and Proliferation: Analysis of the Argentinian Case covers half a century of Gaucho spatial technology, an intense capital-oriented one, and considered as sensitive by central countries dominating the contextualization of semi-peripheral and peripheral territories. This technology implies important levels of industrialization, but military power as well. In here, it is explained the way the discipline of International Relations works from technological politics, portraying the main results of this transversal and supra-national field.

Transitional Justice: The Key to a Negotiated Solution to the Armed Conflict in Colombia highlights the pertinence of peaceful conflict resolution mechanisms, delimiting the concept of transitional justice from the necessity of the reconstruction of societies affected by violence, with the aim of facilitating the transition from war scenarios to contexts of peace, democratic restoration, and respect for human rights. Colombia has developed novel mechanism of transitional justice that have achieved their consolidation as key instruments for the construction of peace in the country as, without them, a concerted solution to the internal armed conflict cannot be visualized; these must resolve the critical dilemma between forgiveness and punishment.

Interventionism and Environment: the Brazilian Amazon Case qualitatively debates the concepts regarding the internationalization of the Amazonian region and the sovereignty of States in the environmental scope. Pondering about it from the Southern perspective, but also considering the Northern position, the article confronts the approaches of developed countries and developing ones in relation with international relations. The divergent notions of sovereignty and environmental responsibility of States are identified as the principal obstacle.

International Hiking and Kidnappings in the Mexican Borderline, 1997-2016 comments on the positive and increasing tendency of tourism to the Aztec territory, placing it in the top 10 of most preferred travel destinations worldwide. Nevertheless, the reception of international hikers in the border territory has been drastically reduced. Such negative tendency, although initiated after the 9/11 terrorists attacks, has deepened due to the increase of kidnappings registered in border states. This negative tendency is analyzed by means of a Vector Auto-Regressive Structural Model which also takes the American GPD into consideration. The results obtained are coherent with the tourism theory, stating 
that the increasing in kidnappings causes a decrease in the arrival of hikers, while growths in the American economy cause the contrary effect.

Lastly, Colombian Foreign Politics 2010-2014: A Turn Towards Autonomy? identifies non-traditional proceedings of the Colombian foreign politics as the diversification of commercial partners, the active participation in multilateral institutions, and a central role in the region's difficult issues, pretending to achieve a certain autonomy without directly challenging the US. This is a kind of soft law, and the article's conceptual framework explains autonomy within the International Relations scope, offering a reconstruction of the evolution of the Colombian foreign politics under the concept of Respice Polum.

With this, we hope to be fulfilling the expectations of our dear and faithful readers, covering the traditional field of the classical school war as well as the horizontalization of the international system, where plenty of transversal issues arise and there is a mutation towards asymmetrical intra-state disputes highly affected by exogenous factors; these sustain, adapt, and develop them within a world stage with a legal façade, but resorting to functional although illegal elements.

Diana Patricia Arias Henao

Editor

$\mathrm{PhD}$ in International Relations revistafaries@unimilitar.edu.co 


\section{EDITORIAL}

Na presente edição o leitor encontrará uma diversidade de temáticas relativas à segurança no sistema internacional, tanto no nível interno como externo, denotando a transversalidade do setor das relações internacionais. Os artigos que compõem esta edição tem sido agrupados em duas seções temáticas: Segurança, geopolítica e ameaças internacionais e Assuntos transversais do sistema internacional contemporâneo.

\section{Segurança, geopolítica e ameaças internacionais}

Em primeira seção temática apresentamos os seguintes artigos:

Mudanças e oportunidades da globalização econômica. É um artigo que, analisa empiricamente os elementos principais do atual processo da globalização econômica: abertura comercial, fluxo da inversão estrangeira direta e movimento de capital, para propor ferramentas críticas à frente dos aspectos positivos e negativos aos que se submetem as sociedades nacionais na abordagem dos governos locais frente a eles, considerando transcendente e por sua vez, a integração desde as instituições internacionais para diminuir a brecha econômica entre países pobres e ricos.

A geopolítica da reforma China. Analisa os retos de tal política exterior na ordem geopolítica regional da Ásia, mediante o estudo de acontecimentos recentes, em especial as disputas territoriais no Mar do Sul da China e examina a pressão regional como promovedora de novos rumos nas suas projeções geopolíticas, por exemplo: a execução do projeto Nova Rota da Seda e o aprofundamento da cooperação com a Rússia. Adicional ao fator externo que representa Estados Unidos da América na Ásia Pacífico, através da denominada Paz longa, gerando rotundas mudanças devido ao constante aumento da economia china e o aumento dos gastos militares, desafiando a outros poderes regionais asiáticos como Índia e Japão para contrariar a influência China na região que observa a participação efetiva de outros sócios como Malásia e Filipinas, propondo uma atitude multidirecional para o Leste e o Oeste de suas fronteiras. 
Práticas de segurança na América Latina durante a Póś-guerra Fria (1992-2010): Complexos regionais ou Comunidades pluralistas de segurança? Mostra como o novo regionalismo de segurança na América durante a Pós-guerra Fria não aporta suficiente evidência empírica, comparada à que permita identificar a existência de Complexos Regionais de Segurança (CRS) ou Comunidades Pluralistas de Segurança (CPS). São estudadas desde dois indicadores as práticas de segurança. São elas: disputas interestatais militarizadas mediante estadísticas descritivas e modelos econométricos e a persistência da hipóteses de conflito em instrumentos programáticos de defesa mediante a análises de conteúdo. Se conclui que a abordagem mais apropriado oferecem os CRS dada a persistência da ameaça e do uso da força como prática de segurança. A premissa da agenda estadunidense na América do Norte, América Central e do Caribe implicam a presença de um CRS centralizado por sua projeção de poder e influência mundial, enquanto que na América do Sul se apresenta um CRS estândar. No nível sub-regional, América Central e a Zona Andina constituem sub-complexos, enquanto que o Cono Sul uma comunidade pluralista de segurança.

Tráfico de droga_e o desafio à_segurança na fronteira andina tripla. Mostra qualitativamente como o tráfico de droga é a principal manifestação do crime organizado em tais territórios de fronteiras acessíveis, onde as vias fluviais e terrestres, sem controle, resultam ser rotas principais para levar droga desde Bolívia e Peru até o Chile, revalorizando a zona como estratégica, que historicamente baixo o paradigma clássico de segurança tem sido protagonista de disputas territoriais persistentes e de origem décimo nono. Aborda a problemática desde o território, Em nos conteúdos da nova agenda de segurança internacional e como ameaça à segurança, e em suas particularidades nacionais e subnacionais.

Chile e a guerra da_Coreia. Um episódio da política exterior chilena. Explica a través da análises documental de arquivos, fontes diplomáticas e secundárias e dentro do contexto da Guerra Fria a posição assumida pelo Chile como consequência das influências ocorridas na América Latina. O enfrentamento Leste-Oeste se apresentou como uma tentação política para o Chile, em quanto as parcerias militares é referido desligando, possivelmente, de Washington. Os resultados se desvelaram em uma estratégia cheia de variáveis com predomínio econômico e diplomático, submetidas a lógicas estratégicas de parcerias em Segurança Hemisférica. 


\section{Assuntos transversais do sistema internacional contemporâneo}

Na segunda seção temática da primeira edição do ano 2017, apresentamos:

Relações internacionais, política tecnológica, desenvolvimento e proliferação: análises do caso argentino. Caminha meio século de tecnologia espacial gaúcha de estirpe capital intensiva, considerada sensivel pelos países centrais e que dominam a contextualização de territórios semiperiféricos e periféricos. Esta tecnologia implica níveis importantes de industrialização, mas também de poder militar, explicando como funciona a disciplina das Relações Internacionais a partir de uma política tecnológica, permitindo assim mostrar os principais resultados de este setor transversal e supranacional.

A justiça transicional: a chave para uma saída negociável ao conflito armado colombiano. Aponta a pertinência dos mecanismos pacíficos de resolução de conflitos, delimitando o conceito de justiça transicional, desde a necessidade de reconstruir sociedades afetadas pela violência, com o fim de facilitar a transição de cenários bélicos a contextos de paz, de restabelecimento democrático e de respeito pelos direitos humanos. Colômbia desenvolveu novos mecanismos de Justiça transicional que tem conseguido consolidar-se como instrumentos necessários para a construção da paz no país e sem os quais não se poderia pensar em uma saída concertada ao conflito armado interno que deve resolver os dilemas críticos entre perdão e o castigo.

Intervencionismo e meio ambiente:_o caso da Amazônia_brasileira. Debate qualitativamente os conceitos relativos à internacionalização da Amazônia e a soberania dos Estados no setor ambiental, reflexionando desde a concepção do Sul, especialmente brasileiro e do Norte, que enfrenta os enfocos dos países desenvolvidos e as nações em via de desenvolvimento nas relações internacionais. Identifica como principal obstáculo as noções divergentes de soberania e responsabilidade ambiental dos Estados.

Excursionismo internacional e sequestros na fronteira do México, 1997-2016. Compreende a tendência positiva e em crescimento do turismo no território azteca, localizando na lisya mundial no top 10 de destinos preferidos pelos viajantes. Sem embargo, a recepção de excursionistas internacionais na fronteira tem sido visto fortemente reduzida; a tal tendência negativa, si bem, teve o seu início com os atentados terroristas do 11S, se aprofundou a partir do aumento dos sequestros registrados nos Estados de fronteiras. Se analisa a tendência negativa desde um Modelo Estrutural de Vectores Autoregressivos, que adiciona à operação o PIB dos EE. UU. Os resultados obtidos são conclusivos com a teoria 
do turismo, que mostra que, o crescimento dos sequestros provoca contrações na chegada de excursionistas, enquanto que o crescimento da economia estadunidense tem o efeito contrário.

Finalizando, Política exterior colombiana 2010-2014: giro à autonomia?, identifica atuações tradicionais da política exterior cafeteira, tais como diversificação de sócios comerciais, participação ativa em instâncias multilaterais e protagonismo em temas álgidos da região, os quais pretendem conseguir margens de autonomia sem confrontar aos EE. UU. Uma espece de softlaw onde um marco conceitual refere à autonomia em Relações Internacionais, uma reconstrução da evolução da política exterior colombiana baixo o conceito de Réspice Polum.

Esperamos saciar as ânsias de nossos reconhecidos e fieis leitores, caminhando pelo cenário tradicional da escola e guerras clássicas até a horizontalizarão do sistema internacional, onde proliferam assuntos transversais e a mutação ao enfrentamentos assimétricos e de predomínio intra-estatal, mas com fortes incidências exógenas, que os mantem, adaptam y desenvolvem, dentro de um cenário mundial de facha legal mas com elementos funcionais ilegais.

Diana Patricia Arias Henao

Editora

Doutora em Relações Internacionais revistafaries@unimilitar.edu.co 